\title{
ТЕАТР-СТУДИЯ КАК СРЕДСТВО СОЦИАЛИЗАЦИИ СТУДЕНТОВ
}

\author{
T.P. Ганзенко \\ Московский гуманитарный университет
}

Аннотация: В статье автор рассматривает театр-студию как средство сочуиализациии студентов, также, указывает на роль театра-студии в вузе в процессе воспитания гармоничной личности и становления нравственно и эстетически просвещенного, образованного человека.

Ключевые слова: студенческий театр-студия, сочиокультурная среда вуза, социиокультурная деятельность

\section{THEATRE STUDIO AS A MEANS OF SOCIALIZING STUDENTS}

\author{
T.R. Ganzenko \\ Moscow University for the Humanities
}

\begin{abstract}
In the article, the author considers the theatre-studio as a means of socializing students, also mentions the role of the theatre-studio in the university in the process of developing a harmonious personality and developing a moral and aesthetic enlightened, educated person.

Keywords: student studio theatre, sociocultural environment of the University, sociocultural activities
\end{abstract}

Актуальная задача современного высшего образования - развитие творческих способностей личности в процессе профессиональной подготовки, раскрытие творческого потенциала студента и создание условий, при которых самореализация будет наиболее полной. К числу таких условий относится создание творческих коллективов, включая театр-студии.

Театр-студия является независимым любительским театральным коллективом, который не требует наличия специальной предварительной подготовки обучающихся. Такие студии занимаются дополнительным образованием, организацией творческой деятельности студентов, тем самым воспитывая в каждом участнике особое восприятие мира и себя в нем.

Одна из задач, которая стоит перед театром-студией заключается в формировании художественной мысли, в формировании восприятия всего многообразия природы и выразительных форм окружающего мира. Иная сторона работы в сфере образования заключается в том, что лидер группы, он же - ее руководитель, обращается к имеющимся проблемам в образовании участников, занимается их нравственно-эстетическим воспитанием (Выготский, 2008). Социокультурная деятельность осуществляет как сохранение, так и передачу культурных ценностей, а также реализовывает потенциал личности, развитие, достижение и поддержание ее определенного статуса в обществе.

Данная работа включает в себя специально разработанные беседы с одним человеком или группой людей, лекции для большого потока, рассказы или 
тренинги о морали и нравственности, темы по культурным вопросам, а такжебеседы о философских учениях. Такая плодотворная и важная работа должна проводиться на постоянной основе, либо во время занятия, либо она должна быть специально организована в то время, которое не предназначено для репетиций студенческого театра-студии.

Правильно выстроенная социально-культурная деятельность благоприятствует полному и организованному развитию человека, что обусловливает развитие и формирование будущих педагогов-психологов с профессиональной стороны.

Согласно Федеральному государственному образовательному стандарту высшего образования (51.03.03, Социально-культурная деятельность), организация социально-культурной среды представляет собой одно из обязательных условий для выполнения основных образовательных программ бакалавриата. Следовательно, необходимо создавать такие условия, которые могут способствовать общественному и личностному развитию, а также совершенствованию абсолютно всех сфер жизни личности студента, которые в совокупности и формируют социально-культурную среду (ФГОС, 2012).

Согласно статьям 75 «Дополнительное образование детей и взрослых» и 76 «Дополнительное профессиональное образование» Федерального закона об образовании №273 дополнительное профессиональное образование строится на компетентностном подходе. Он должен быть реализован в равной степени в программах любой продолжительности (Закон об образовании в РФ, 2012).

Студенческий театр, безусловно, также является частью дополнительного профессионального образования, в котором потребность в установлении и развитии контактов между индивидами, а также интерес к творческим достижениям выходят на главный план. Ведь важно сформировать побуждение к действиям, которые станут сильными побудительными моментами для исходной точки социально-культурной деятельности.

Психологи, педагоги, атакжесоциологи, на основе информации овоздействии искусства на человека, сделали вывод, что у многих людей возникает интерес к абсолютно всем видам искусства, но они в большой степени уступают по уровню развития и образования тем личностям, у которых выявлены предпочтения лишь в определенных видах творческой деятельности. Поэтому, для начала лучше заинтересовать участников творческого процесса каким-то одним видом искусства, чем пытаться вызвать любовь ко всему разнообразию культуры.

Художественно-просветительская работа заключается в том, чтобы научить членов театрального коллектива в большей степени повысить навыки аналитического мышления и постигать смысл искусства. Для достижения этого перед прослушиванием руководитель ставит конкретные вопросы, на которые каждый обучающийся должен самостоятельно найти ответы, прежде 
чем слушать композицию, смотреть спектакль или танцевать. Чтобы ответить на вопросы, которые перед ними стоят, участники должны четко определить собственное отношение к произведению искусства, при этом, они должны суметь объяснить его разумным образом. Опытно-экспериментальная работа, которая осуществлялась по данной методике в различных театральных труппах, дает право говорить о ее высоком отношении между достигнутым результатом и использованными ресурсами, а также о ее подчиненности конкретной цели. При этом, чувственность искусства перемещается в активно осознанное, т.е., человек может ограничивать себя пассивным просмотром. Также устанавливаются определенные исходные оценочные позиции. При данном подходе к искусству уже невозможно «привязывать» такие формы, которые не могут заключать в себе соответствие личным представлениям и предпочтениям.

Художественная и образовательная работа включает два взаимозависимых аспекта: просмотр или прослушивание, а также анализ произведений искусства обучающимися и развитие теоретических знаний об установленном художественном жанре. Просмотр или прослушивание способствуют овладению разными моделями мышления, накапливают художественные и чувственные впечатления, улучшают чувственное познание и значимость произведений искусства, содействуют повышению производительности, а также - росту художественных навыков. Все, что нужно для просмотра и анализа,- это использовать понятные для студентов произведения.

Театр-студия как средство социализации студентов, оказывает помощь в развитии универсальных, общепрофессиональных и обязательных профессиональных компетенций студентов.

В Федеральном государственном образовательном стандарте Высшего образования 3++, 52.03.05 «Театроведение», указано, что к универсальным компетенциям относятся:

- системное и критическое мышление. Оно определяет способность к поиску, критическому анализу и обобщению информации. А также системный подход к решению проблем;

- разработка и реализация проектов. Данная компетенция устанавливает способность определять набор определенных задач в рамках поставленной цели и выбирать наилучшие способы их решения на основе действующих правовых норм, доступных ресурсов и ограничений;

- командная работа и лидерство, которая означает умение вести социальные взаимодействия и выполнять свою роль в команде;

- коммуникация, которая обосновывает способность вести деловое общение в устной и письменной форме на государственном языке Российской Федерации и иностранных языках;

- межкультурное взаимодействие предполагает под собой способность 
воспринимать разнообразие культур общества в историческом, социальном, философском и этическом контекстах;

- самоорганизация и саморазвитие. Означает умение грамотно планировать свое время, формировать и реализовывать траекторию своего развития, опираясь на принципы образования в течении всей своей жизни. А также, в нее входит способность поддерживать соответствующий уровень физической подготовки с целью обеспечения активной социальной, а также профессиональной деятельности.

К общепрофессиональным компетенциям относятся:

- история и теория искусства. Она предполагает, что студент научится не только понимать, но и применять принципы изобразительных средств искусства на конкретном этапе истории;

- творческая деятельность означает способность реализовывать творческую деятельность в сфере культуры и искусства;

- работа с информацией предполагает, что студент научится производить поиск информации в сфере культуры и искусства, в том числе с помощью информационных и коммуникативных функций, а также применять найденную информацию в своей профессиональной деятельности;

- педагогическая деятельность, которая означает способность планировать процесс образования, разрабатывать методические материалы, проводить анализ различных педагогических методов в сфере культуры и искусства;

- государственная культурная политика. Умение разбираться в проблематике актуальной государственной культурной политики Российской Федерации (ФГОС, 2012).

Организация студенческого театра-студии как средства формирования социальной среды вуза, основана на применении совокупности педагогических подходов, которые позволяют определить полную картину социально-культурной деятельности учащихся. Сюда относятся:

- личностный подход, который опирается на естественное развитие творческойсовокупностивозможностейчеловека, которыйтакжепредусматривает самостоятельную работу с каждым студийцем с целью стать единым целым с желаемым им образом;

- деятельностный подход, который формирует деятельность всей театральной труппы. Коммуникация в театре-студии способствует развитию у участников анализа собственных поступков и переживаний, человек ощущает необходимость в своем преображении и воплощает данную необходимость в процессе собственного развития. У каждого из участников студии есть возможность попробовать себя в разных социальных ролях, помимо этого, они могут проанализировать свои товарищеские и организационные особенности;

- полисубъектный, или диалогический подход, который создает потребность 
человека в его процветании. В театре-студии проявляется и создается единство чувств, замыслов, точек зрения, а также, участники добиваются взаимного понимания друг с другом. Помимо этого, возникает обмен и восприятие стилей поведения, наклонностей, стереотипов, возникают командные взаимоотношения и единодушие (Алексеева, 2014).

Таким образом, социокультурная деятельность в театре-студии относится к условиям этического развития личности, где рост человека воспринимается как процесс бесчисленных связей и сопоставленных перемен в двух вариантах: внутреннем, что означает ориентацию «на себя», и внешнем, который подразумевает ориентацию «на других». Студенты становятся участниками социально-ценностных взаимоотношений и начинают обладать соответствующими личностными качествами личности.

Также зарождается совокупность определенных особенностей и свойств каждого из студентов в конечном итоге становления личности и познания самого себя.

Подводя итоги, следует отметить, что театральные студии являются средством воспитания гармоничной личности подростков. Как и любой другой вид искусства, театр-студия несет функции воспитания, которые можно воплотить только в театральных труппах и творческих группах. Если грамотно сформировать педагогическую, воспитательную работу, то она позволит учащимся более плодотворно находить решение задач, которые стоят перед студентами, а также добиваться желаемых результатов.

\section{СПИСОК ЛИТЕРАТУРЫ}

Алексеева М.С. (2014) Студенческий театр как средство формирования социокультурной среды вуза // Современные научные исследования и инновации. № 11. Ч. 3 [Электронный ресурс] // URL: http://web.snauka.ru/issues/2014/11/39892 (дата обращения: 24.10.2020).

Выготский Л.С. (2008) Педагогическая психология. М.: АСТ, 672 с.

Федеральный Государственный Образовательный Стандарт Высшего Образования 3++. 51.03.03, (2012) Социально-культурная деятельность [Электронный ресурс] // URL: http://gosvo.ru/fgosvo/92/91/4/94 (дата обращения: 08.11.2020).

Федеральный Государственный Образовательный Стандарт Высшего Образования 3++. (2012) 52.03.05. п. 3.2, 3.3 [Электронный ресурс] // URL: http:// fgosvo.ru/fgosvo/92/91/4/94 (дата обращения: 11.11.2020).

Федеральный Закон об образовании в РФ № 273, (2012). [Электронный реcypc] // URL: http://www.consultant.ru/document/cons_doc_LAW_140174/2f0cff66d89 6f7b9817e26dba7e5f3207df5c43e/ (дата обращения: 08.11.2020).

Ганзенко Татьяна Романовна - магистрант 2 курса, кафедры педагогики и 
психологии высшей школы Московского гуманитарного университета. Научный руководитель: кандидат психологических наук, доцент Е.Е. Иванова. Адрес: 111395, Россия, г. Москва, ул. Юности, д. 5. Тел.: 8(925)845-86-85. Эл. адрес: tanya-ganzenko@yandex.ru.

Ganzenko Tatyana Romanovna - master's degree in pedagogy and psychology of higher school of Moscow University for the Humanities. Scientific Director: Candidate of Psychological Sciences, Associate Professor E.E. Ivanova. Address: 111395, Russia, Moscow, St. Youth, D. 5. Tel.: 8(925)845-86-85. E-mail: tanya-ganzenko@yandex.ru. 